\title{
DIVERSITATEA HELMINTOFAUNEI LA CÂINII MAIDANEZI ÎN DEPENDENȚĂ DE VÂRSTĂ ȘI BIOTOP
}

\section{Rusu Ștefan, Erhan Dumitru, Chihai Oleg, Zamornea Maria, Gologan Ion, Chihai Nina', Pruteanu Mihail, Rusu Vadim²}

Institutul de Zoologie al MECC, or. Chișinău, Republica Moldova

'Liceul Teoretic "Lucian Blaga", mun. Bălți, Republica Moldova

${ }^{2}$ Universitatea de Stat din Moldova, or. Chișinău, Republica Moldova

E-mail: rusus1974@yahoo.com

https://doi.org/10.53937/9789975315975.58

\begin{abstract}
More than 1200 biological samplings were collected from the free-ranging dogs of various ages and biotopes that allowed to study the diversity of their helminth fauna. The results of investigations revealed that $95 \%$ of researched dogs are infested with multiple parasites mostly endoparasites (Eimeria canis, Dipilidium caninum, Echinococcus granulosus, Toxocara canis, Toxascaris leonina, Ancylostoma caninum and Trichocephalus vulpis.). It was established that the level of contamination with the all above mentioned parasites in free-ranging dogs is hogher in the adult dogs compared to the young ones. The young dogs were predominantly infested with parasites from the class Sporozoite (Eimeria canis) and the Nematoda class (Toxocara leonina). The level of contamination with parasites of the free-rangeging dogs is higher in the rural regions compared to the urban area.
\end{abstract}

Key words: helminth fauna, free-ranging dogs, level of contamination, biotopes, age.

\section{INTRODUCERE}

Este demonstrat, că la etapa actuală nici un efectiv de animale (nivel populaţional) și nici un animal-gazdă (nivel individual) nu este infestat numai cu o singură specie de paraziţi. Pentru numeroase efective de animale domestice și sălbatice, în special bovine, ovine, porcine, păsări și câini este caracteristic fenomenul poliparazitismului $[3 ; 4 ; 7 ; 8]$. Gazda poliparazitată este supusă unei acţiuni patogene de către întregul complex parazitar, în structura căruia au loc multiple și diverse relații cu efecte complexe $[10 ; 11 ; 12]$. 
Rezultatele obținute relevă că atât animalele domestice, cât și cele sălbatice din Republica Moldova au un grad sporit de infestare cu diverse specii de ecto- și endoparaziţi în formă de mono- și poliinvazii, iar în unele cazuri constituind cca 100\% [2]. Organismul animalului poliparazitat este supus, permanent, acțiunii stresogene și ca rezultat scad nu numai indicii productive, dar și rezistența organismului la dverse maladii: infecțioase, bacteriene, micotice etc. Canidele, fiind gazde definitive și intermediare pentru diverși agenți parazitari, constituie un pericol invaziv pentru animalele domestice și sălbatice. Diminuarea capacităţii productive a animalelor domestice, constituie ce-a mai mare și frecventă categorie de pierderi cauzate de căinii maidanezi, ca gazde definitive, intermediare, complementare etc. La bovinele infestate scade producţia de lapte cu cca 46\%, carne - 43\%, iar natalitatea cu 61\%. Producţia de lână la ovine scade în mediu cu 27-30\%. Unii savanţi constată că la animalele infestate cu Echinococcus granuposus larvae, comparativ cu cele neinfestate, conţinutul de vitamine $A$ și $E$ la nivelul ficatului este de trei ori mai mic; al vitaminelor $B_{1}$ ș $B_{2}$ - de 1,2 ori, vitamina $C$ de 1,6 ori, iar conţinutul de $\mathrm{Fe}-2,6$ ori. În musculatură vitamina $\mathrm{A}$ scade de 3,7 ori, $E-1,4$ ori, $B_{1}-1,2$ ori, $B_{2}-1,3$ ori, și vitamina $C$ de 4,2 ori $[3 ; 4 ; 9]$. Deci, pierderile economice estimate în urma parazitozelor, la care câinele este gazdă definitivă, sunt enorme.

Supravegherea parazitologică sistematică a câinilor maidanezi, prin examene periodice, cu elaborarea unor măsuri de combatere, va duce la scăderea semnificativă a infestărilor animalelor domestic, sălbatice și a omului cu diverși agenți parazitari $[1 ; 5 ; 6]$.

\section{MATERIALE ȘI METODE}

În scopul stabilirii diversităţii parazitofaunei la câinii maidanezi, în dependenţă de vârstă și biotop, au fost supuse investigării peste 1200 probe coprologice. Investigațiile, cu privire la determinarea speciilor de paraziți, s-au efectuat în Laboratorul de Parazitologie și Helmintologie. La realizarea obiectivelor propuse au fost utilizate metode coproovoscopice (Fulleborn, Darling), coprolarvoscopice (Popov, Baermann) și a spălării succesive. 


\section{REZULTATE ȘI DISCUŢII}

Investigaţiile parazitologice la tineretul canin din sectoarele rurale a pus în evidenţă un nivel înalt de infestare cu endoparaziţi intestinali: Eimeria canis de 35,9\%, Dipilidium caninum - 18,5\%, Echinococcus granulosus 6,3\%, Toxocara canis - 12,6\%, Toxascaris leonina - 64,9\%, Ancylostoma caninum - 9,4\% și Trichocephalus vulpis - 6,2\% (fig. 1).

Câinii adulţi din sectoarele urbane erau infestați cu Eimeria canis în 2,9\% cazuri, Dipilidium caninum - 25,5\%, Echinococcus granulosus - 14,3\%, Toxocara canis - 39,6\%, Toxascaris leonine - 1,9\%, Ancylostoma caninum 7,4\% și Trichocephalus vulpis în 10,5\% cazuri, iar câinii adulţi din sectoarele rurale erau infestați cu Eimeria canis în 4,2\% cazuri, Dipilidium caninum - 47,3\%, Echinococcus granulosus - 42,7\%, Toxocara canis - 52,8\%, Toxascaris leonine - 12,4\%, Ancylostoma caninum - 16,2\% și cu Trichocephalus vulpis în 24,6\% cazuri (fig. 2).

Studiul diversităţii speciilor de paraziţi la câinii maidanezi relevă, că nivelul de infestare este mai înalt la cei adulţi în comparaţie cu cei tineri. Rezultatele obţinute denotă că nivelul de infestare cu paraziţi din clasa Sporozoa (Eimeria canis) și clasa Nematoda (Toxocara leonina) a tineretului canin este mai înalt, în comparaţie cu cei adulţi, iar al câinilor vagabonzi din sectorul rural prevalează în comparaţie cu acei din sectorul urban.

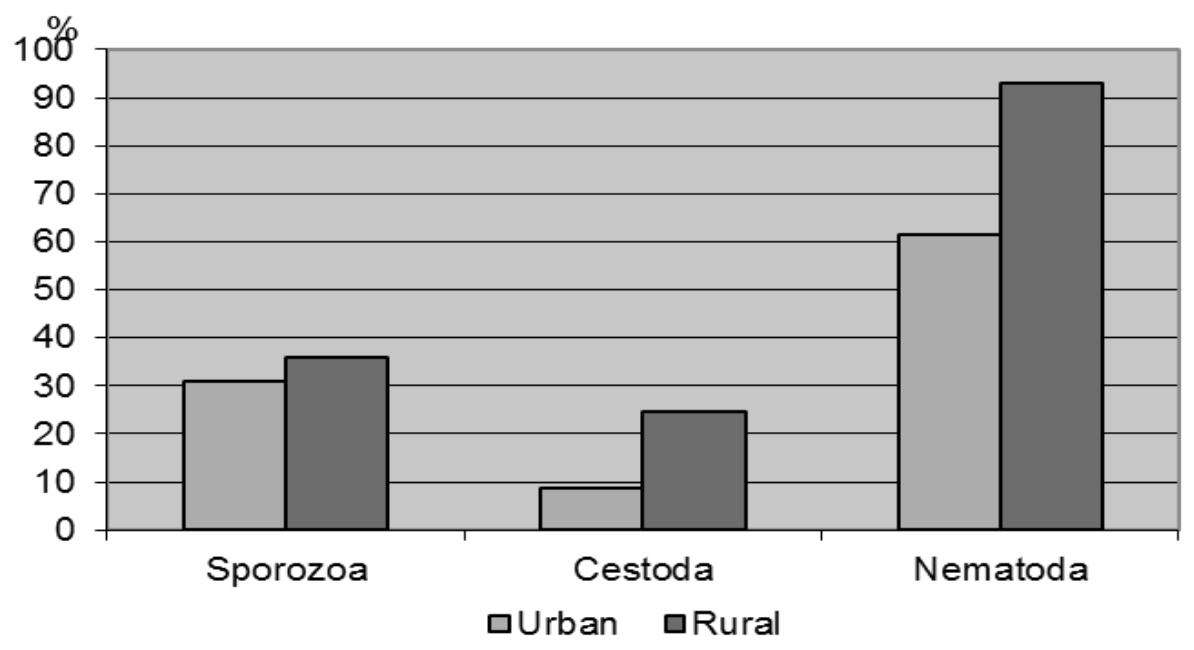

Figura1. Diversitatea endoparaziţilor la tineretul canin maidanez din sectoarele rurale şi urbane din mun. Chişinău 


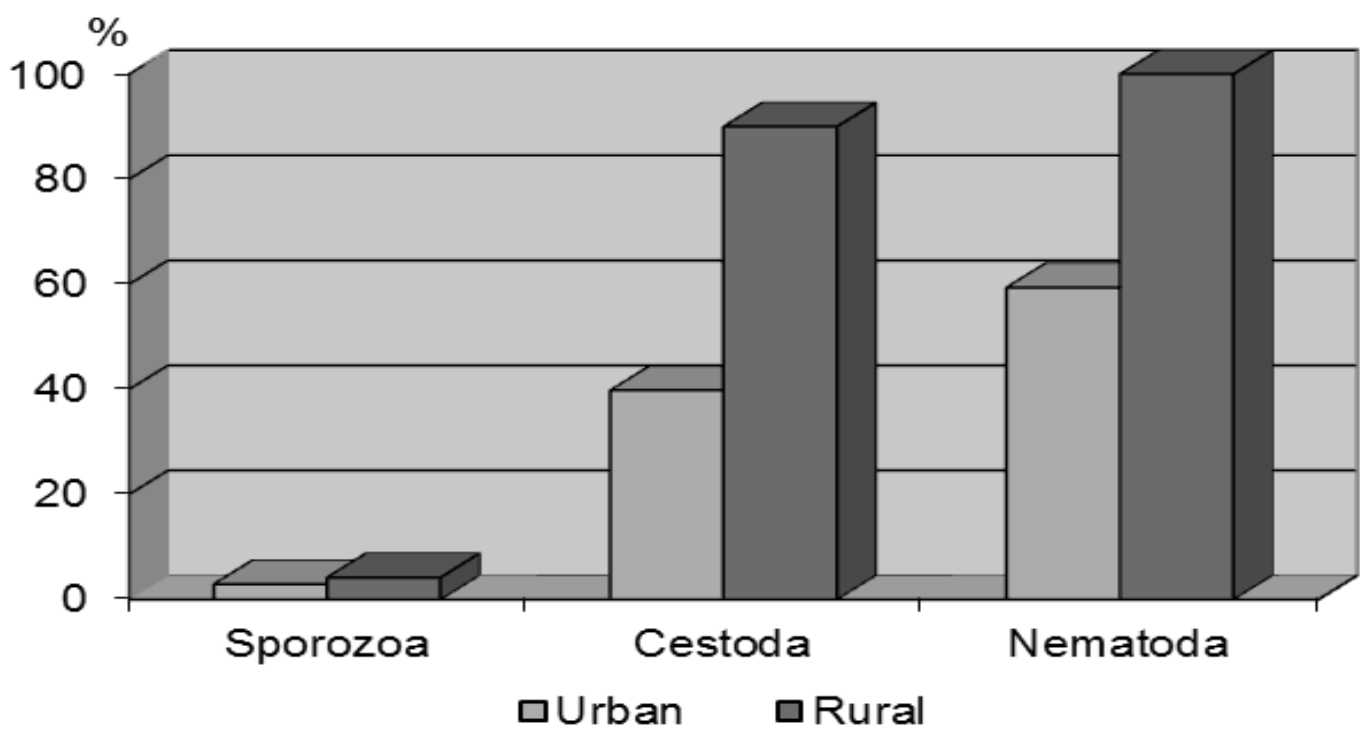

Figura 2. Diversitatea endoparaziţilor la câinii maidanezi adulţi din sectoarele rurale şi urbane din mun. Chişinău

În scopul stabilirii diverselor forme parazitare vehiculate în diverse biotopuri de către câinii maidanezi din mun. Chișinău, au fost supuse investigării peste 700 probe biologice de sol.

În rezultatul acestui studiu, s-a stabilit că nivelul de poluare al solului cu ouă de Echinococcus granulosus și Toxocara canis din diverse biotopuri este variat și destul de înalt (tab.1).

Tabel. Prezenţa ouălor de Echinococcus granulosus şi Toxocara canis în sol din diverse biocenoze

\begin{tabular}{|l|c|c|c|c|c|c|}
\hline \multirow{2}{*}{ Biotopurile studiate } & \multicolumn{2}{|c|}{ Echinococcus granulosus } & \multicolumn{3}{c|}{ Toxocara canis } \\
\cline { 2 - 7 } & $\begin{array}{c}\text { Total } \\
\text { probe }\end{array}$ & $\begin{array}{c}\text { Probe pozi- } \\
\text { tive }\end{array}$ & $\begin{array}{c}\text { El, } \\
\text { \% }\end{array}$ & $\begin{array}{c}\text { Total } \\
\text { probe }\end{array}$ & $\begin{array}{c}\text { Probe pozi- } \\
\text { tive }\end{array}$ & $\begin{array}{c}\text { El, } \\
\%\end{array}$ \\
\hline Instituţii preșcolare & 242 & 10 & 5,0 & 242 & 26 & 11,0 \\
\hline $\begin{array}{l}\text { Terenuri din preajma } \\
\text { spaţiilor locative }\end{array}$ & 46 & 8 & 18,0 & 46 & 38 & 83,0 \\
\hline Plaje & 12 & 2 & 17,0 & 12 & 7 & 59,0 \\
\hline Zone de odihnă & 34 & 7 & 21,0 & 34 & 22 & 65,0 \\
\hline \multicolumn{1}{|c|}{ Total } & $\mathbf{3 3 4}$ & $\mathbf{4 3}$ & $\mathbf{1 3 , 0}$ & $\mathbf{3 3 4}$ & $\mathbf{9 3}$ & $\mathbf{2 8 , 0}$ \\
\hline
\end{tabular}


S-a constatat, că solul din preajma instituţiilor preșcolare este poluat cu ouă de Echinococcus granulosus în 5,0\% cazuri, iar cu Toxocara canis în 11,0\% cazuri. Investigaţiile parazitologice a terenurilor din preajma spaţiilor locative au stabilit un nivel de poluare al solului cu ouă de Echinococcus granulosus de 18,0\%, iar cu Toxocara canis de 83,0\%.

De asemenea, cercetările solului din diverse plaje și zone de odihnă a pus în evidenţă un nivel de poluare al acestora cu ouă de Echinococcus granulosus respectiv în 17,0\% și 21,0\% cazuri, iar cu Toxocara canis, respectiv în 59,0\% și 65,0\% cazuri.

Așadar, s-a constatat că solul din preajma instituţiilor preșcolare, este poluat cu ouă de Echinococcus granulosus în 5,0\%, iar cu Toxocara canis în 11,0\% cazuri. Investigaţiile parazitologice a terenurilor din preajma spaţiilor locative au stabilit un nivel de poluare al solului cu ouă de Echinococcus granulosus de 18,0\%, iar cu Toxocara canis de 83,0\% cazuri.

Cercetările probelor de sol din diverse locuri ale plajei și zonei de odihnă a pus în evidenţă un nivel de poluare al acestora cu ouă de Echinococcus granulosus, respectiv în 17,0\% și 21,0\% cazuri, iar cu Toxocara canis, respectiv în 59,0\% și 65,0\% cazuri.

\section{CONCLUZII}

1. S-a estimat că 95\% din câinii maidanezi cercetaţi sunt infestaţi în formă de poliinvazii.

2. S-a stabilit că câinii maidanezi din mun. Chișinău sunt infestați cu Eimeria canis, Dipilidium caninum, Echinococcus granulosus, Toxocara canis, Toxascaris leonina, Ancylostoma caninum și Trichocephalus vulpis.

3. Nivelul de infestare, cu majoritatea speciilor de endoparaziţi, a câinilor maidanezi este mai înalt la cei adulţi, în comparaţie cu cei tineri.

4. S-a stabilit că infestarea cu paraziţi din clasa Sporozoa (Eimeria canis) și clasa Nematoda (Toxocara leonina) a tineretului canin este mai înaltă în comparaţie cu cei adulţi.

5. Extensivitatea invaziei câinilor vagabonzi din sectorul rural prevalează în comparaţie cu acei din sectorul urban. 
Investigațiile au fost realizate în cadrul proiectului 15.817.02.12F, finanțat de Consilul Supărem pentru Știință și Dezvoltare Tehnologică al Academiei de Științe a Moldovei.

\section{BIBLIOGRAFIE}

1. Chihai O., Erhan D., Tălămbuţă N., Lungu V., Rusu Ș., Cresciuc O. Parazitofauna la Canis familiaris din mun. Chișinău Republica Moldova. În: Revista Română de Parazitologie. 2009, Vol. 19, nr.1-2, p.18-19.

2. Erhan D., Pavaliuc P., Rusu Ș. Potenţialul adaptiv și productiv al bovinelor la acţiunea factorilor stresogeni. Chișinău: Tipogr. AȘM, 2007. 224 p.

3. Olteanu Gh., Panaitescu D., Gherman I. ș. a. Parazitozoonoze. Probleme la sfârșit de mileniu în România. - București. - 1999. - 592 p.

4. Olteanu Gh. ș. a. Poliparazitismul la om, animale, plante și mediu. București, 2001. $812 \mathrm{p}$.

5. Rusu Șt. Câinele (Canis familiaris) - importantă sursă de invazie pentru om și mediu. În: Materialele Simpozionului internaţional "Diversitatea, valorificarea raţională și protecţia lumii animale", consacrat jubileului 70 de ani din ziua nașterii profesorului universitar Andrei Munteanu. Chișinău: Știinţa, 2009, p. 216-219.

6. Rusu Șt., Chihai O., Anghel T. Diversitatea parazitofaunei la câinii vagabonzi din municipiul Chișinău. În: Simpozion știinţific internaţional: 35 ani de invăţământ superior medical veterinar din Republica Moldova, 15-16 octombrie 2009. Chișinău, 2009, p. 254-258.

7. Șuteu I., Cozma V. Parazitologie clinică veterinară. Cluj-Napoca, 2007, vol. 1. 316 p.

8. Șuteu I., Cozma V. Parazitologie clinică veterinară. Cluj-Napoca, 2007, vol. 2. 349 p.

9. Tratat de medicină veterinarăî. Coordonator Nicolae Constantin. Cluj-Napoca. Editura Risoprint. 2014, Vol. VI. 1340 p.

10. Абуладзе К. И., Аемидов Н. В., Непоклонов А. А. Паразитология и инвазионные болезни с-х животных. - М.: «Агропромиздат». -1990.- 464 с.

11. Ааугалиева Э.Х. Изучение гистоглобулина на организм животных при некоторых гельминтозах //Паразитарные болезни с-х животных и меры борьбы с ними. - Алма-Ата, 1979. - С. 47.

12. Ерхан А. К., Панасюк А. И., Панасюк С. А., Ятусевич А. И. Гельминты и простейшие - резервуарные хозяева и возбудители гиперпаразитарных сочетанных инфекционных и инвазионных болезней. - Кишинев: Штиинца. 1995. - 334 с. 